\title{
Depth perception in the dark-reared rat as a function of time in the dark
}

RICHARD D. WALK, SAMUEL TRYCHIN, JR. AND BERNARD Z. KARMEL

GEORGE WASHINGTON UNIVERSITY

\begin{abstract}
Abstraet
Dark-reared hooded rats were tested for depth perception on the visual cliff. Ss were given an equal density condition to equate retinal angle presented during testing. Ss were kept in the dark from birth and tested after 40-170 days without visual stimulation. Darkreared Ss 90 days of age, and perhaps to 125 days of age, discriminated depth. No group kept in the dark 140 days of longer discriminated depth.
\end{abstract}

\section{Problem}

The hooded rat can discriminate depth after 3 months in the dark. Lashley \& Russell (1934) showed that rats raised in the dark for 100 days exert more force in jumping to distant platforms than to near ones. Walk, Gibson, \& Tighe (1957) tested 90 day old hooded rats on a visual cliff $20 \mathrm{~min}$. after emergence from the dark. They found that the animals descended from a center board to a glass surface with a textured pattern just beneath it (the "shallow" side) in preference to a glass surface with a patterned surface 53 in below the glass (the "deep"'side). Nealey \& Edwards (1960) allowed 90 day old animals no patterned visual experience prior to testing them on a model of the visual cliff similar to that of Walk, Gibson, \& Tighe and also found depth discrimination in the dark-reared Ss.

Walk \& Gibson (1961) repeated the dark-reared studies with 30 day old and 90 day old rats and controlled for texture density cues. The pattern was 10 in beneath the glass and of larger textured elements than the pattern directly under the glass so that elements of equal density or equal retinal angle were projected to the animal's eye. They concluded that the dark-reared Ss could discriminate depth even when the major remaining cue was that of motion parallax, the differential motion of close as compared to distant textured elements as the animal moved its head.

Nealey \& Riley (1963), on the other hand, reared hooded rats for 300 days in the dark and then tested them on an equal density condition. The deep side was 10 in below the glass and contained stripes parallel to the center board, wider stripes 10 in below the glass than just beneath it to equate retinal angle. These Ss did not discriminate depth on this equal density condition or on a 53 in replica of the Walk, Gibson, \& Tighe visual cliff. The light-reared controls did. After a period of 34 days in the light, the dark-reared Ss discriminated depth on the 53 in visual cliff.

The present experiment reports a series of studies carried out over a $4 \mathrm{yr}$. period when animals were raised in the dark and tested on the equal density condition of the visual cliff. Period in the dark ranged from 40-170 days. It is known that hooded rats discriminate depth after 90-100 days in the dark, but they cannot discriminate it after 300 days without light. The purpose of the present study was to determine more accurately the time required for the hooded rat to "lose" depth discrimination as a function of time in the dark. In addition, younger dark-reared animals were tested to replicate the original findings, that some dark-reared rats can discriminate depth when texture density is equated on both sides of the center board.

\section{Procedure}

Ss, hooded rats, were placed in the dark soon after birth. They remained in the dark until tested. Animals kept over 60 days in the dark were separated from the mother and male and female Ss placed in different cages. A flashlight with a red filter over the lens was used during the separation procedure, at about age 60 days, which lasted approximately $5 \mathrm{~min}$.

Ss were tested individually on the visual cliff, one trial for each $S$, on emergence from the dark. About 5-10 min. light adaptation was allowed prior to testing.

The visual cliff apparatus is like a glass bottomed box with inside.dimensions 20 in by 32 in with 14 in high sides to restrict S's vision. The $\mathrm{S}$ was placed on a gray center board 4 in wide, 4 in high and 20 in long on top of and bisecting the glass. Directly under the glass on one side of the center board was a $1 / 4$ in pattern of red and white checks while a $3 / 4$ in similar pattern was 10 in below the glass on the other side of the board. The apparatus is illustrated in Walk (1965).

Ss were allowed $3 \mathrm{~min}$. for descent from the center board. The place for the shallow or deep sides (east or west from the center board) was changed after every four to six Ss to control for environmental cues. Both sides of the glass were cleaned after each $\mathrm{S}$ was tested.

\section{Results}

The results are shown in Table 1, which also includes animals run under similar conditions by Walk \& Gibson (1961). If one divides the Ss into those 90 days of age or younger ( $\mathrm{N}$ descending $=51$ ), comparable to other studies which have found no loss of the depth response in darkreared hooded rats, one finds $76 \%$ descents to the shallow side, a highly significant preference. $(z=3.641$, $\mathrm{p}<.001$ ). The 40 and 80 day old, previously unreported, rats in Table 1, part of the group of 51 Ss 90 days of age or younger, went $78 \%$ to the shallow side $(z=2.500$, $\mathrm{p}<.02)$. The present study thus replicated the Walk \& 
Table 1. Performance on the Visual Cliff with Retinal Angle Equated of Dark-Reared Hooded Rats Deprived of Light 30-170 Days.

$\begin{array}{ccccc}\begin{array}{c}\text { Age } \\ \text { (Days) }\end{array} & \mathrm{N} & \text { Shallow } & \text { Deep } & \text { No Descent } \\ 30^{*} & 20 & 13 & 4 & 3 \\ 40 & 16 & 12 & 2 & 2 \\ 80 & 19 & 6 & 3 & 10 \\ 90^{*} & 12 & 8 & 3 & 1 \\ 125 & 14 & 7 & 2 & 5 \\ 3.40 & 35 & 7 & 9 & 19 \\ 150 & 38 & 5 & 12 & 21 \\ 170 & 37 & 10 & 9 & 18 \\ & & & \end{array}$

Gibson (1961) results. On the other hand, animals of 125-170 days of age ( $\mathrm{N}$ descending $=61$ ) went $48 \%$ to the shallow side $(z=0.26$, n.s. $)$, showing no significant preference.

Table 1 also shows that $78 \%$ of the 125 day old Ss (N descending $=9$ ) went to the shallow side, while no group 140 days of age or over discriminated depth. Because of the small $\mathrm{N}$ the preference of the 125 day old Ss is not significant.

A large increase in the "no descent" category in the older dark-reared, a finding similar to that of Nealey \& Riley (1963), is shown in Table 1. The increase in "emotionality" in the dark-reared Ss makes them difficult and wasteful to use as Ss. Table 1 shows 191 Ss, but only 112 (59\%) descended from the center board within $3 \mathrm{~min}$. Of the $67 \mathrm{Ss}$ less than 100 days old, $76 \%$ descended while only $49 \%$ of the 124 Ss over 100 days old descended from the center board.

Some of the 140 day old animals $(\mathrm{N}=21)$ were tested after 2, 13 and 28 days in the light. After 2 days in the light the animals went 6 shallow, 11 deep, 4 no descent.
After 13 days in the light 9 shallow, 6 deep, 6 no descent, and after 28 days in the light 7 shallow, 4 deep and 10 no descents were observed. The animals did not recover visual function on the visual cliff immediately but the preference for the shallow side was partially reasserted after two weeks in the light.

\section{Diseussion}

This study shows that the hooded rat loses the capacity to discriminate depth on the visual cliff, under these conditions, with prolonged lack of visual stimulation, replicating Nealey \& Riley (1963), and shows that the time in the dark required for this loss is no longer than 5 mo. or half the 10 mo. period in the dark of the Nealey and Riley study. It is a reasonable hypothesis, based on the performance of the $\mathbf{1 2 5}$ day old Ss, that the hooded rat can still discriminate depth after as much as $4 \mathrm{mo}$. of visual deprivation, but notafter 5 mo. or more without light.

\section{References}

Lashley, K. S., \& Russell, J. T. The mechanism of vision: XI. A preliminary test of innate organization. J. genet. Psychol., 1934, 45, 136-144.

Nealey, S. M., \& Edwards, B. J. "Depth perception" in rats without pattern-vision experience. J. comp. physiol. Psychol., 1960, $53,468-469$.

Nealey, S. M., \& Riley, D. A. Loss and recovery of discrimination of visual depth in dark-reared rats. Amer. J. Psychol., 1963, 76, 329-332.

Walk, R. D. The study of visual depth and distance perception in animals. In D. S. Lehrman, R. Hinde and E. Shaw (Eds.), Advances in the study of behavior. Vol. 1. New York: Academic Press, 1965. Pp. 99-154.

Walk, R. D., \& Gibson, E. J. A comparative and analytical study of visual depth perception. Psychol. Monogr., 1961, 75, No. 519 1-44.

Walk, R. D., Gibson, E. J., \& Tighe, T. J. Behavior of light- and dark-reared rats on a visual cliff. Science, 1957, 126, 80-81.

Note

1. This research was supported in part by grants $(10714,19411$ and GB 272) from the National Science Foundation. The authors are grateful for the assistance of Thomas Curtis and Thomas Quinta in carrying out the experiment. 